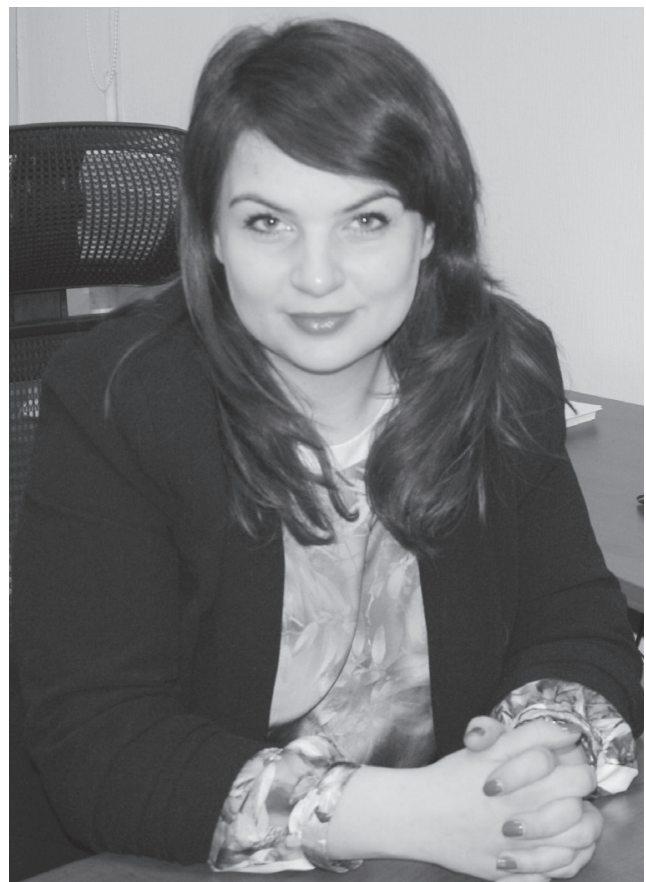

Marusheva Oleksandra Anatoliivna, PhD in Law, Associate Professor of the Department of Public Administration, Doctoral research scholar of the Department of Public Administration; Interregional Academy of Personnel Management, 03039, Kyiv, Str. Frometivska, 2, tel.: +38 (067) 89594 85, e-mail: marusheva.o@gmail.com

ORCID: 0000-0001-9126-4674

\title{
СТРАТЕГІї РЕГУЛЮВАННЯ СОЦІАЛЬНО-ЕКОНОМІЧНИХ ВІДНОСИН У БУДІВНИЦТВІ
}

Анотація. 3'ясовано, що основою методологічного базису державного регулювання соціально-економічних відносин у будь-якій галузі є концепція. Для виокремлення сучасних концепцій та стратегій насамперед визначено особливості соціально-економічних відносин у сфері будівництва та недоліки державного регулювання даної сфери. 3 огляду на розглянуті аспекти виявлено, що останніми роками значного поширення набувають новітні концепції та стратегії державного регулювання соціально-економічних відносин у будівництві, а саме: неоінституційна концепція; концепція FutureStep; концепція “активізуючої держави”; концепція політичних мереж; мікростратегічна концепція; концепція “управління за результата- 
ми”; концепція змін; концепція або стратегія державно-приватного партнерства. Кожна з наведених стратегій передбачає забезпечення гнучкого механізму державного регулювання соціально-економічних відносин з послідовним удосконаленням його взаємодії з різними сферами державної діяльності. Обгрунтовано, що застосування наведених концепцій та стратегій сприяє посиленню впливу на швидкість економічних процесів, підвищенню ефективності рішень в аспекті державного регулювання будівельної галузі. Зокрема, розглянуті стратегії, поєднуючи різні підходи та інструменти, дають можливість ефективно координувати процеси та суб'єкти управління, більше фокусуватись на аспекті стійкого розвитку, ефективно вирішувати нагальні суспільні проблеми, стимулювати істотне підвищення продуктивності праці в галузі, здійснювати ефективне управління в умовах непередбачуваних чинників (наприклад, концепція або стратегія державно-приватного партнерства створює можливість зосередитись на плануванні та забезпеченні виконання великомасштабних будівельних проектів).

Ключові слова: стратегія, концепція регулювання, соціально-економічні відносини, будівництво, будівельна галузь, державне регулювання.

\section{СТРАТЕГИИ РЕГУЛИРОВАНИЯ СОЦИАЛЬНО-ЭКОНОМИЧЕСКИХ ОТНОШЕНИЙ В СТРОИТЕЛЬСТВЕ}

Аннотация. Установлено, что основой методологического базиса государственного регулирования социально-экономических отношений в любой отрасли является концепция. Для выделения современных концепций и стратегий прежде всего определены особенности социально-экономических отношений в сфере строительства и недостатки государственного регулирования данной сферы. Учитывая рассмотренные аспекты, выявлено, что в последние годы широкое распространение приобретают новейшие концепции и стратегии государственного регулирования социально-экономических отношений в строительстве: неоинституционная концепция; концепция FutureStep; концепция “активизирующего государства”; концепция политических сетей; микростратегическая концепция; концепция “управления по результатам”; концепция изменений; концепция или стратегия государственно-частного партнерства. Каждая из приведенных стратегий предусматривает обеспечение гибкого механизма государственного регулирования социально-экономических отношений с последовательным совершенствованием его взаимодействия с различными сферами государственной деятельности. Обосновано, что применение приведенных концепций и стратегий способствует усилению влияния на скорость экономических процессов, способствует повышению эффективности решений в аспекте государственного регулирования строительной отрасли. В частности, рассмотренные концепции и стратегии, сочетая различные подходы и инструменты, позволяют более эффективно осуществлять координацию процессов и субъектов управления, в большей степени фокусироваться на ас- 
пекте устойчивого развития, эффективно решать насущные общественные проблемы, стимулировать существенное повышение производительности труда в отрасли, осуществлять эффективное управление в условиях непредсказуемых факторов (например, концепция или стратегия государственночастного партнерства дает возможность сосредоточиться на планировании и обеспечении выполнения крупномасштабных строительных проектов).

Ключевые слова: стратегия, концепция регулирования, социально-экономические отношения, строительство, строительная отрасль, государственное регулирование.

\section{STRATEGIES FOR REGULATION OF SOCIO-ECONOMIC RELATIONS IN CONSTRUCTION}

Abstract. The article clarifies that a concept is the basis of the methodological fundament of government regulation of socio-economic relations in any field. In order to distinguish between modern concepts, the peculiarities of socio-economic relations in the field of construction and the disadvantages of state regulation of this sphere are determined first of all. Taking into consideration the considered aspects, it was discovered that in recent years, the new concepts of state regulation of social and economic relations in construction have become widespread: the neoinstitutional concept; "FutureStep" concept; the concept of "Activating State"; the concept of Policy Networks; Micro Strategy concept; concept of "Management by Objectives"; Change concept; the concept of a Public-Private Partnership. Each of the above mentioned strategies provides for a flexible mechanism for government regulation of socio-economic relations with the consistent improvement of its interaction with various spheres of state activity. It is proved that applying the concepts and strategies given in the article contributes to the impact on the speed of economic processes, the efficiency of decisions in the aspect of government regulation of the construction industry. In particular, the article considers strategies, combining different approaches and tools that allow more effective coordination of processes and management entities, more focus on the aspect of sustainable development, allows to solve urgent problems effectively, stimulate a significant increase in labor productivity in the industry, to carry out effective management in conditions of unpredictable factors, and for instance, the concept or strategy of a public-private partnership creates an opportunity to focus on planning and ensuring the implementation of large-scale construction projects.

Keywords: concept, concept of regulation, socio-economic relations, construction, construction industry, government regulation.

Постановка проблеми. Значні зміни середовища життєдіяльності (інтенсифікація інформаційних потоків, розвиток телекомунікацій, фінансової сфери тощо), які сталися на рубежі XX-XXI ст., змінили роль простору і часу в управлінні та діяльності виробничо-економічних 
підприємств і сприяли розвитку та формуванню нових концепцій та моделей управління, що знаходять своє відображення й у державному управлінні будівельною галуззю. Фактично відбулося утворення нової економічної формації, гнучкої та мобільної, що управляється економічними потоками, спроможна змінювати сфери діяльності та споживання багатств. Інакше кажучи, це свідчить про зміну сучасної соціально-демократичної парадигми управління на таку, що в більшій мірі відповідає запитам інформаційного суспільства, базується на плюралізмі, нових потребах і цінностях, методах тощо. Отже, постала необхідність у визначенні нових концепцій та стратегій устрою соціально-економічних відносин у галузі будівництва.

Аналіз останніх досліджень та публікацій. Дослідженнями у даній сфері займалися такі провідні науковці та дослідники, як I. Брайловський, О. Вінник, О. Гаман-Голутвина, А. Дегтярев, О. Залуніна, К. Листратов, I. Мальковська, В. Мелко, К. Павлюк, Л. Шульгіна, Л. Шутенко та ін. На даному етапі особливої уваги потребує питання сучасних концепцій регулювання соціально-економічних відносин.

Формулювання цілей (мети) статті. Метою даної статті є аналіз сучасних стратегій та концепцій регулювання соціально-економічних відносин у будівництві та їх визначальний вплив.

Виклад основного матеріалу. Основу методологічного базису державного регулювання соціальноекономічних відносин у будь-якій галузі складає концепція. Наукова концепція, як теоретичний імператив, повинна відображати як способи розуміння процесів та явищ, що відбуваються, так і дослідити шляхи вирішення виявлених проблем, запропонувати напрями економічного зростання та розвитку. Будь-яка наукова концепція відображає найважливіші положення, які узгоджують i пов'язують теоретичні знання з практичним досвідом. Засади та підходи певної наукової концепції можуть реалізовуватись як певна стратегія державного регулювання соціально-економічних відносин.

Аналітики зазначають, що будівництво є пріоритетною галуззю розвитку економіки, але в умовах кризи необхідно особливу увагу приділяти дослідженню факторів впливу на будівельний сектор країни [1]. При цьому одним із вирішальних факторів впливу на будівельну галузь $є$ ефективність державного регулювання. Ефективність функціонування галузі будівництва безпосередньо залежить від механізмів державного регулювання. Державне регулювання будівництва варто розглядати як комплекс заходів державних органів законодавчого, виконавчого і контрольного характеру, спрямованих на стабілізацію та адаптацію чинної економічної системи до мінливих умов розвитку країни (регіону) [2].

Основні учасники соціальноекономічних відносин з будівництва можуть виконувати різні функції i залежно від цього отримувати відповідне найменування, а саме [3, с. 536]:

1) інвестор - це суб'єкт інвестиційної діяльності у сфері капітального будівництва, який приймає рішення про вкладення власних, по- 
зичкових або залучених коштів (інвестицій) в об’єкти інвестування, що належать до основних фондів;

2) замовник - це суб'єкт інвестиційної діяльності в галузі капітального будівництва, що замовляє у підрядника виконання проектно-вишукувальних, будівельних та пов'язаних з ними робіт. У ролі замовника може виступати сам інвестор або уповноважена ним особа, у тому числі консалтингова та/або інжинірингова організація, що спеціалізується на будівництві;

3) підрядник - організація чи індивідуальний підприємець, що на договірних засадах за плату підряджається виконувати на замовлення замовника проектно-вишукувальні, будівельні та пов'язані з ними роботи.

Особливості соціально-економічних відносин у сфері будівництва визначаються продукцією будівництва - введеними в дію виробничими потужностями, об'єктами невиробничого призначення та інфраструктури, включаючи необхідне для їх експлуатації обладнання. Особливостями техніко-економічного характеру є [4]:

- неоднорідність і своєрідність виробленої продукції, яка відрізняється за характером виробництва i функціональним призначенням, що вимагає індивідуальних підходів до кожного споруджуваного об'єкта, враховуючи його призначення та використання, місце будівництва, вимоги замовника;

- нерухомість будівельних об'єктів (будівництво відбувається, зазвичай, у тому самому місці, де використовується), що вимагає мо- більності засобів виробництва, адже протягом процесу будівництва всі засоби виробництва і робоча сила повинні переміщуватись на будівельному майданчику залежно від фаз технологічного циклу, а це суттєво збільшує виробничі витрати, пов'язані із транспортуванням, монтажем, демонтажем обладнання, будівельних машин і механізмів, переміщенням робочої сили тощо;

- вплив на виробничий процес природно-кліматичних умов, що вимагає для кожного конкретного випадку своїх конструктивно-компонувальних рішень, зміни оплати праці будівельників залежно від умов виконання робіт, пори року, температурного режиму тощо;

- вплив фактора часу, що виявляється у досить тривалому виробничому циклі, який, своєю чергою, зумовлює тривалі терміни окупності капітальних вкладень і наявність незавершеного виробництва;

- високий рівень одноразових витрат, необхідних для початку виробничого циклу і виведення коштів з обороту на тривалий період, що означає їх фактичне замороження до певного часу;

- специфічні товарні відносини між виробником та споживачем будівельної продукції, що виникають ще до початку виробничого процесу і реалізуються через систему договірних відносин.

При цьому функціонування держави пов'язане 3 трансакційними витратами. I вони тим більше, чим у більшій кількості трансакцій держава виступає як гарант виконання умов контракту. Чим активніша роль держави в специфікації і захисті прав 
власності, тим складніше внутрішня структура апарату управління і більше інформації, що циркулює в ній, спотворюється. Тому поряд 3 “провалами” ринку варто враховувати i “провали” держави, до числа яких на сьогодні можна віднести [2]:

- невідповідність доходів і витрат - державу значно важче перетворити на банкрута, навіть якщо вона виявляється нездатною виконувати взяті на себе зобов'язання;

- відсутність чітких критеріїв ефективності діяльності держави: державні структури підміняють їх самостійно розробленими стандартами, i тоді діяльність держави оцінюється заданими нею самою критеріями (зростання бюджетних надходжень, експансіі державного контролю тощо);

- висока ймовірність досягнення результатів, відмінних від поставлених завдань: зростання інформаційних витрат і витрат моніторингу та контролю, що супроводжує розвиток держави, створює передумови для відхилення реалізованих завдань від поставлених;

- нерівномірний розподіл ресурсів підприємницьких структур, у зв'язку з чим доводиться вибирати між двома недосконалими альтернативами: розподіл прав власності здійснюеться на основі ринкового обміну, що функціонує без витрат, з приватними гарантіями виконання контракту та передачею контролю за обміном повноваженнями державі, що діє в інтересах сторін контракту.

3 огляду на досліджувані аспекти, варто зазначити, що останніми роками значного поширення набувають новітні концепції та стратегії держав- ного регулювання соціально-економічних відносин у будівництві:

- неоінституційна концепція;

- концепція FutureStep;

- концепція “активізуючої держави";

- концепція політичних мереж;

- мікростратегічна концепція;

- концепція "управління за результатами";

- концепція змін;

- концепція або стратегія державно-приватного партнерства.

Кожна 3 наведених стратегій передбачає забезпечення гнучкого механізму державного регулювання соціально-економічних відносин 3 послідовним вдосконаленням його взаємодії з різними сферами державної діяльності.

Якщо говорити про сутність нової інституційної теорії та iㅡ практичної цінності в галузі дослідження державного управління, то вона робить акцент на "аналізі трансакційних витрат”, формуючи оригінальну теоретичну базу для вирішення проблеми ефективності різних інституційних форм та координації взаємодій між різними суб'єктами управління. На думку представників цієї теорії, враховуючи трансакційні витрати, можна домогтися найбільшої ефективності публічного управління [5].

Концепція FutureStep - це новий процес стратегічного управління, який допомагає компаніям, особливо великим багатонаціональним корпораціям, що адаптуються, зробити такі характеристики компанї̈, як гнучкість і швидке реагування, невід'ємною частиною кожного аспекту своєї діяльності. Цей підхід до стратегічного управління є модуль- 
ним інструментом. Його частини можуть бути використані як незалежно, так і в рамках цілої програми як інструкція із стратегічного ухвалення рішень. Основна увага фокусується на тому, що організація може зробити сьогодні, аби збільшити свою здатність до адекватних дій і стійкого розвитку соціально-економічних відносин у майбутньому [6].

У межах концепції "активізуючої держави” завдання органів державного управління визначаються під час суспільної дискусії, а між суспільством і державою розвивається співробітництво і розділяється відповідальність. Держава ініціює процеси вирішення суспільних проблем і виступає в ролі посередника; встановлює рамки відповідальності громадян у цих рамках. Таким чином, найважливішими функціями держави стають ініціювання, активізація і стимулювання. Модель "активізуючої держави” передбачає побудову та вивчення держави у чотирьох вимі$\operatorname{pax}[7]$ :

- держава як гарант забезпечення виробництва та надання послуг;

- держава як надавач послуг для суспільства, якщо це диктують, наприклад питання безпеки або якщо держава може це зробити з меншими витратами, ніж інші суб'єкти;

- держава як інститут, що створює рамки суспільної активності та умови громадянам для вирішення проблем;

- держава як інститут нагляду за суспільною та економічною діяльністю.

Основним елементом наступної концепції є поняття “політична мережа” (policy network) [8]. У загально- му вигляді під мережею розуміється система державних і недержавних суб’єктів у певній сфері політики, які взаємодіють між собою на базі ресурсної залежності з метою досягнення згоди з певного питання, використовуючи при цьому формальні й неформальні норми [9]. Варто зазначити, що відповідно до цієї концепції соціально-економічні відносини більше не контролюються виключно державними суб'єктами влади, інструменти є розсіяними, а матеріальні ресурси, що є об'єктами цих відносин, розподіляються між різноманітними учасниками зазначених відносин. Функція координування учасників соціально-економічних відносин більше не належить центральному керівництву, а формується шляхом цілеспрямованих інтеракцій між індивідуальними суб'єктами ринку.

Ще однією концепцією стала мікростратегічна концепція "Мікростратегії як альтернатива довгостроковому стратегічному плануванню в умовах невизначеності", яку розробили Д. Логан і X. Фішер-Райт. Дослідивши дані про діяльність приблизно 24 тис. осіб майже за 10 років, автори дійшли висновку, що найбільш успішними були ті лідери, які в своїй роботі використовували мікростратегії (стратегії, орієнтовані на короткий термін), рухаючись від однієї короткострокової мети до іншої. Мікростратегії складаються у певну систему більш-менш важливих планів. Замість того, щоб заздалегідь планувати всі майбутні кроки, краще розбивати їх на мікростратегії. Це дасть змогу організації вчитися і коригувати свої дії у процесі досягнення глобальної мети [10]. 
Концепцію “управління за цілями, результатами” (MBO - Management by Objectives), яка переживає сьогодні своє "відродження", розробив у середині 60 -х років XX ст. американський вчений П. Друкер, один з найвідоміших фахівців у галузі менеджменту та маркетингу. Він вважав, що дана концепція - це метод підвищення ефективності організації, згідно з якою діяльність будь-якого працівника оцінюється не за процесом, а за результатом, якщо результат розуміється як досягнення поставленої цілі, завдання. Практика використання $\mathrm{MBO}$ показала, що П. Друкер був правий: основні вигоди, які несе впровадження даної системи в організації, - це підвищення продуктивності праці за рахунок чітких орієнтирів у кожного працівника організації та підвищення вмотивованості персоналу за рахунок його участі в постановці власних завдань [5].

Концепція змін грунтується на тому, що ефективна формальна стратегія повинна містити в собі основні ланцюги, найбільш істотні елементи обмежувальної політики, та послідовність основних дій. Ефективні стратегії розвиваються навколо декількох ключових концепцій і напрямів розвитку соціально-економічних відносин. Стратегія має справу не тільки з непередбачуваними, але і з невідомими чинниками. У складній організації повинна бути ієрархія взаємопов'язаних і підтримуючих стратегій між різними учасниками відносин [11].

Під концепцією або стратегією державно-приватного партнерства переважно розуміється узгодження цілей і забезпечення балансу інтересів держави і бізнесу в рамках реалізації соціально-економічних проектів, націлених на досягнення спільної вигоди. У даному трактуванні ДПП включає в себе всі форми кооперації між державою і приватним сектором не тільки в економіці, але і в інших сферах суспільного життя - політиці, культурі, науці [12].

Залежно від трактування сутності партнерства до його базових ознак відносять [13]:

- сторонами державно-приватного партнерства є держава і приватний бізнес, а також суспільство;

- взаємодія сторін закріплюється на офіційній, юридичній основі;

- взаємодія сторін має рівноправний характер;

- державно-приватне партнерство має чітко виражену публічну, суспільну спрямованість;

- у процесі взаємодії на основі державно-приватного партнерства консолідуються, об'єднуються ресурси і вклади сторін;

- фінансові ризики і затрати, а також досягнуті результати розподіляються між сторонами у визначених наперед пропорціях.

Водночас I. Брайловський, досліджуючи державно-приватне партнерство, визначає, що потенційні вигоди використання такої форми економічної взаємодії, як державно-приватне партнерство можуть складатися з того, що даний формат взаємин бізнесу і влади може забезпечити [14]:

- більшу ефективність, а також економію часу при реалізації проектів і здійсненні робіт за рахунок використання учасниками парт- 
нерства своїх найбільш сильних сторін;

- різноманітність у підходах до розробки i подальшого здійснення проектів за рахунок використання різних методів і розширення числа можливих варіантів;

- більш високу якість економіко-управлінських рішень при реалізації спільних проектів, що забезпечується кваліфікацією представників бізнесу і найбільш повне врахування суспільних потреб і соціальної значимості, яку забезпечують представники органів управління;

- інтеграцію суб'єктів бізнесу в громадське життя за рахунок його безпосереднього залучення до реалізації соціально-значущих проектів;

- підвищення якості надаваних товарів і послуг за рахунок установлення більш жорсткого державного контролю;

- зниження соціальної напруги i негативного відношення до бізнесу 3 боку населення за рахунок визнання його внеску у вирішенні соціальних проблем.

Використання зазначеної форми взаємодії між державою та приватним сектором набуває поширення переважно в тих будівельних проектах, де існує потреба та ряд можливостей щодо вирішення великомасштабних завдань соціально-економічної сфери.

\section{Висновки і перспективи подаль-} ших досліджень. Визначено вісім концепцій та стратегій регулювання соціально-економічних відносин у будівництві. Підсумовуючи викладене, можна передбачити, що досліджені концепції та стратегії у розгляді сучасної моделі державного регулю- вання соціально-економічних відносин у будівельному комплексі дають можливість розробити теоретичну модель досліджуваного об'єкта, сформувати системний підхід у проведенні досліджень в галузі будівництва, а також обрати ефективний метод вирішення окреслених питань. Важливим заходом у вирішенні соціально-економічних проблем у будівельному комплексі є застосування регулюючих базисів, які спроможні впливати на швидкість економічних процесів, сприяти підвищенню ефективності рішень в аспекті державного регулювання, а також змінювати можливу дистанцію у наявних відмінностях. Комплексне питання більш ефективного застосування концепцій державного регулювання соціально-економічних відносин у будівництві потребує подальших наукових досліджень.

\section{СПИСОК ВИКОРИСТАНИХ ДЖЕРЕЛ}

1. Залуніна О. М. Розвиток будівельного сектору України за останні роки / О. М. Залуніна // Наук. вісн. Херсон. держ. ун-ту. Серія: Економічні науки. - 2014. - Вип. 5. - Ч. 1. C. $174-177$.

2. Шутенко Л. М. Будівельна галузь як об’єкт державного регулювання / Л. М. Шутенко // Синергетичні аспекти формування економічних параметрів будівельних структур в умовах ринку : матер. Міжнар. наук.-практ. інтернет-конф. / Харків, обл. держ. адм., Харків, нац. акад. міськ. госп-ва. - Харків : ХНАМГ, 2011. - C. 5-6.

3. Вінник О. М. Господарське право : навч. посіб. для студ. вищ. навч. закл. - 2-ге вид., змін. та допов. / 
О. М. Вінник. - К. : Правова єдність, 2009. - $766 \mathrm{c}$.

4. Мелко В. Л. Теоретичні підходи до державного регулювання галузі будівництва / В. Л. Мелко // Державне управління. - 2017. - № 1 (57). C. 61-68.

5. Мальковская И. А. Трансформация государства и эволюция публичного администрирования в условиях глобализации / И. А. Мальковская // Вестник Российского ун-та дружбы народов. Политология. 2006. - № 8. - C. 27-43.

6. Шульгіна Л. М. Сучасні концепції стратегічного управління інноваційним розвитком підприємства / Л. М. Шульгіна, В. В. Юхименко // Маркетинг i менеджмент інновацій. - 2011. - № 3 (2). - С. 79-84.

7. Гаман-Голутвина О. Меняющаяся роль государства в контексте реформ государственного управления: отечественный и зарубежный опыт / О. Гаман-Голутвина // Полис. 2007. - № 4. - C. 46-58.

8. Дегтярев А. А. Принятие политических решений / А. А. Дегтярев. - М. : КДУ, 2004. - 416 с.

9. Листратов К. Е. Управление политическими проектами: теория, методология, реальная политика / К. Е. Листратов // Вестник Моск. ун-та. Политические науки. 2007. - № 6. - C. 20-30.

10. Dave Logan, Halee Fischer-Wright. Micro strategies: The key to successful planning in uncertain times [Текст] // Leader to Leader. - 2009. - № 54. P. 45-52.

11. Henry Mintzberg. The Strategy Process / Henry Mintzberg, James Brian Quinn, Sumatra Ghoshal. - 1998, p. $5-13$.

12. Брайловський I. A. РЕST-класифікація ризиків державно-приватного партнерства / I. А. Брайловський / / Схід:аналітично-інфор- маційний фаховий наукометричний журн. - 2013. - № 1 (121). C. $15-19$.

13. Павлюк К. В. Сутність і роль державно-приватного партнерства в соціально-економічному розвитку держави / К. В. Павлюк, С. М. Павлюк // Наук. пр. Кіровоградського нац. технічного ун-ту. Економічні науки. - 2010. - Вип. 17. - С. 10-19.

14. Брайловський I. А. Мета і зміст державно-приватних партнерств / I. А. Брайловський // Технологический аудит и резервы производства. - 2014. - № 1 (5). - С. 52-54.

\section{REFERENCES}

1. Zalunina O. M. (2014). Rozvytok budivelnoho sektoru Ukrainy za ostanni roky [Development of the building sector of Ukraine in recent years]. Naukovyi visnyk Khersonskoho derzhavnoho universytetu. Seriia: Ekonomichni nauky - Scientific Bulletin of the Kherson State University. Series: Economic Sciences, 5, 1, 174-177 [in Ukrainian].

2. Shutenko L.M.(2011). Budivelna haluz yak obiekt derzhavnoho rehuliuvannia [Construction industry as an object of state regulation]. Synerhetychni aspekty formuvannia ekonomichnykh parametriv budivelnykh struktur $\mathrm{v}$ umovakh rynku - Synergetic aspects of formation of economic parameters of building structures in market conditions: Proceedings of International scientific practical internet conference. (p. 5-6). Kharkiv: KhNAMH [in Ukrainian].

3. Vinnyk O. M. (2009). Hospodarske pravo [Economic Law]. ( $2^{\text {nd }}$ ed., rew). Kyiv: Pravova yednist [in Ukrainian].

4. Melko V. L. (2017). Teoretychni pidkhody do derzhavnoho rehuliuvannia haluzi budivnytstva [Theoretical Approaches to State Regulation of the 
Construction Industry]. Derzhavne upravlinnia - Public Administration, 1 (57), 61-68 [in Ukrainian].

5. Malkozskaya I. A. (2006). Transformatsiya gosudarstva i evolyutsiya publichnogo administrirovaniya v usloviyakh globalizatsii [Transformation of the state and evolution of public administration in the conditions of globalization]. Vestnik Rossiyskogo universiteta druzhby narodov. Politologiya - Bulletin of The Peoples' Friendship University of Russia. Political science, 8, 27-43 [in Russian].

6. Shulhina L. M., Yukhymenko V. V. (2011). Suchasni kontseptsii stratehichnoho upravlinnia innovatsiinym rozvytkom pidpryiemstva [Contemporary Concepts of Strategic Management of Innovative Development of the Enterprise]. Marketynh i menedzhment innovatsii - Marketing and Management of Innovations, 3 (2), 79-84 [in Ukrainian].

7. Gaman-Golutvina O. (2007). Menyayushchayasya rol gosudarstva $\mathrm{v}$ kontekste reform gosudarstvennogo upravleniya: otechestvennyy i zarubezhnyy opyt [The changing role of the state in the context of public administration reforms: domestic and foreign experience]. Polis, 4, 46-58 [in Russian].

8. Degtyarev A. A. (2004). Prinyatie politicheskikh resheniy [Making political decisions]. Myiv: KDU [in Russian].

9. Listratov K. E. (2007). Upravlenie politicheskimi proektami: teoriya, me- todologiya, realnaya politika [Political Project Management: Theory, Methodology, Real Politics]. Vestnik Moskovskogo universiteta. Politicheskie nauki - Moscow University Bulletin. Political science - 6, 20-30 [in Russian].

10. Logan D., Fischer-Wright H. (2009). Micro strategies: The key to successful planning in uncertain times. Leader to Leader, 54, 45-52 [in English].

11. Mintzberg H., Brian Q. J., Ghoshal S. (1998). The Strategy Process. London; New York: Prentice Hall [in English].

12. Brailozskyi I. A. (2013). PEST-klasyfikatsiia ryzykiv derzhavno-pryvatnoho partnerstva [PEST-classification of risks of public-private partnership]. Skhid - East, 1(121), 15-19 [in Ukrainian].

13. Pavliuk K. V., Pavliuk S. M. (2010). Sutnist i rol derzhavno-pryvatnoho partnerstva v sotsialno-ekonomichnomu rozvytku derzhavy [The essence and role of public-private partnership in the socio-economic development of the state]. Naukovi pratsi Kirovohradskoho natsionalnoho tekhnichnoho universytetu. Ekonomichni nauky Scientific works of Kirovohrad national technical university. Economic Sciences, 17, 10-19 [in Ukrainian].

14. Brailovskyi I. A. (2014). Meta i zmist derzhavno-pryvatnykh partnerstv [Purpose and content of public-private partnerships]. Tekhnologicheskiy audit i rezervy proizvodstva - Technological audit and production reserves, 1 (5), 52-54 [in Ukrainian]. 